\title{
Paving Paradise William Morris at the Galleries
}

\author{
Susan Belyea
}

Kathanine A. Lochnan, Douglas E. Schoenherr, and Carole Silver, eds., The Earthly Paradise: Arts and Crafts by William Morris and His Circle From Canadian Collections (Toronto: Art Gallery of Ontario \& Key Porter Books Limited 1993).

Nineteen-Hundred and Ninety-Three was the Year of William Morris. In the craft studio where I work at Harbourfront Centre in Toronto, there were slide lectures, guest artists from Britain, exhibitions of functional decorative work, all explicitly linked in one way or another to the legacy of William Morris, "the father of the arts and crafts movement.' Above all of this, there was anticipation and speculation about the upcoming exhibit, "The Earthly Paradise," which featured work by Morris and his contemporaries. This exhibit, which toured several Canadian cities in 1993, was drawn from Canadian collections, and curated by the Art Gallery of Ontario. The exhibit is catalogued and elaborated upon in a wonderful book published jointly by the Art Gallery of Ontario and Key Porter Books.

I looked forward to seeing the installation of Morris' work, for I had encountered him in books a few years earlier at the craft and design college I attended. Mostly, I knew that he was a pioneer in the life that I aspired to: he was a successful designer and craftsperson. In school, we learned little about his actual designs and production work per se, and even less about his political analysis. Mostly I knew that he was a financially successful craftsperson who understood the importance of beautiful surroundings and useful objects in everyday life. Much later I learned that he was one of Britain's important socialist voices at the end of the nineteenth century, and one of E.P.Thompson's heroes.

William Morris (1834-1896) was a designer, a craftsman, a businessman, a writer, a publisher, and a socialist. He designed, made, and marketed wallpaper, furniture, stained glass, ceramics, woven and printed textiles, carpets, and books, among other things. His writings - poetry, fictional prose, and essays - reflected his desire to be part of a revolution transforming the alienation and squalor of the nineteenth century world he knew into "an earthly paradise" for all.!

As a craftsperson, I looked forward to the opportunity to view original Morris works. Though I knew the reputation of Morris and Co. as designers and makers of

1 This phrase, from which the title of the exhibit comes, was the title of a series of narrative verse drawn from Greek Mythology, medieval romance, and folklore which Morris published in a series of volumes between 1868 and 1870

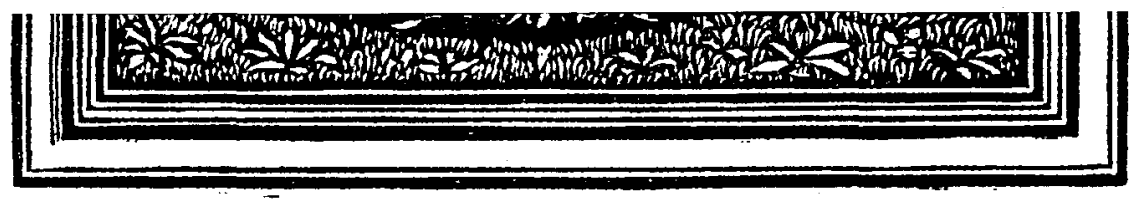

WILLIAM MORRIS, Three Female Musicians from The Earthly Paradise. 
a wide range of things, like many I was familiar with only some of his more famous surface designs on fabric and wallpaper. I was also curious to see how a mainstream fine art gallery would display items generally regarded as craft. There has long been a split between "fine art" and "craft". This schism predates Morris and indeed was the subject of many of his essays. A goal of his was to bridge the split between the fine arts and the "lesser arts" as he called them, encouraging artists to apply their painterly and sculptural skills to functional and decorative objects. Despite his efforts and the efforts of many twentieth-century artists, craftors, curators, and art theorists, the split remains significant in the art/craft world. Given this, I was eager to see how the "lesser arts" or decorative arts would be curated and exhibited by the Art Gallery of Ontario a mainstream, 'fine art' gallery. I was also curious to see where and how Morris' politics would fit into the exhibit.

I was not disappointed, in fact, I enjoyed "The Earthly Paradise" enough to see it twice: once in Toronto at the Art Gallery of Ontario and again at the National Gallery in Ottawa. On my first visit I was in the process of moving into a new house. I was preoccupied with paint, fabric and design ideas, and so I experienced the show as a visit to a big, exquisite home decorating emporium. Initially I thought this reaction was rather funny; treating a visit to the AGO as though I were at Ikea. Upon reflection, though, I think that Morris' concern with making the home a place of beauty and function was probably a perfect entry point for many people's enjoyment of the entire exhibit.

The show was set up in a series of rooms and halls each dedicated to a specific aspect of Morris' work and/or life. Moving through the exhibit, viewers got a sense of the times in which William Morris lived and worked, and of the ideas which drove him. The exhibit addressed his design process, the inspiration behind his work, and the technical processes he used. To a much lesser extent, it touched on his idealism and political analysis.

One of the strongest points of the exhibit was an elaborate installation demonstrating the technique used in printing multi-colored intricate patterned fabric and paper. There was a video of the production process, a long table showing the various steps, and some finished products. A similar exhibit was set up showing the 'production' of books. Viewers were shown how subject or content were matched with text, paper, spacing, illustration, and binding, resulting in a product of incredible beauty.

This focus on technical aspects of producing work is unusual for a show in an art gallery. Context, technique, inspiration and ideology are rarely addressed in these venues. That each of these aspects held a place in "The Earthly Paradise" was one of the greatest accomplishments of the show.

As a survey of the life and work of William Morris this show was circumscribed by the fact that it was work drawn only from Canadian collections, by no means the most complete representation of Morris' work. While much of this work is now owned by museums, archives, and libraries, it would be an interesting research project to explore the circumstances and political views of the original importers of Morris' work into Canada. One collector, for example, was moral reformer and social purity 
activists David A. Watt, a major player in the Montreal Society for the Protection of Women and Girls in the 1880s. Is this an ironic co-incidence, or reflective of some intriguing historical relationship?

I went to "The Earthly Paradise" prepared to be critical. Like many leftists I was sure that William Morris' politics would be given short shrift, and to an extent they were. Others voiced a similar criticism. Rick Salutin, in his obituary of E.P. Thompson in the Globe and Mail, referred briefly to the Morris show, noting that "the display mostly ignored the fact that Morris was Britain's leading socialist voice in the latter part of his life."

Salutin is right, there were few overt references to Morris' socialist politics. There was much more of an emphasis on a kind of poetic idealism, 'quotable quotes' writ large on posters throughout the exhibit. The most memorable of all - relevant to many, not just those of us moving house - was: " Have nothing in your houses which you do not know to be useful or believe to be beautiful." A lovely idea, but hardly a call to revolution.

Careful perusal of some of the manuscripts and correspondence in the exhibit gave a sense of more complex politics. There is one letter in particular in which Morris explains to James Mavor why, until after the revolution it is regrettably impossible to produce handmade high quality chairs at a price affordable to the average worker. This letter struck a chord in me as I too "spend my life in ministering to the swinish luxury of the rich". ${ }^{3}$

In general, the bits and pieces of the show that did reference Morris' political life as a socialist writer, speaker and organizer were not highlighted in the exhibit. On the other hand, E. P. Thompson's book on the life and politics of William Morris, brilliant as it is, fails to give us a good look at his wallpaper designs. ${ }^{4}$

"The Earthly Paradise" as an art exhibit - and more so The Earthly Paradise as a book - give useful insight into the design process and products of Morris and his contemporaries. That Morris' design decisions and systems of production evolved directly out of his critique of industrial capitalism was made obvious. So, while the exhibit did not explicitly address Morris' socialism, his critique of capitalism was clear. It also did a fine job in presenting William Morris as a brilliant and ground breaking designer. His work with pattern, form, and colour stand up to scrutiny a century after his death. The work of William Morris (and Co.) is in many ways, the work that we all (craftors) want to design and make. It is beautiful, balanced, and functional. Clearly it stands the test of time. While his drive came in large part from his political convictions, his excellence in design and production are worthy of careful attention on their own.

William Morris and his colleagues spearheaded a craft revival in Europe which called into question many things about our relations to the objects which surround

The Globe and Mail, 10 September 1993.

Letter from William Morris to James Mavor dated 16 April, 1887.

E.P. Thompson, William Morris: Romantic to Revolutionary (London 19555, 1977) 
us. Morris also raised important questions about the way in which things are made, and the relationship between consumers, makers the means of production. These questions are still enormously relevant. In the late 1960 s and early 1970 s, a similar movement evolved as part of a larger counter culture in North America, and the 'hippie craftsperson' was born. Those of us who still perversely persist in doing non-alienated labour in the face of almost certain poverty and artistic compromise can benefit from a visit to the world of William Morris. There we can find solace and hope, and support for the belief that beautiful objects are still worth making.

Three cheers for the Socialist Revolution ... For till it comes art must be in the hands of the monopolists and their parasites - whereof I am one.

Yours regretfully, William Morris ${ }^{5}$

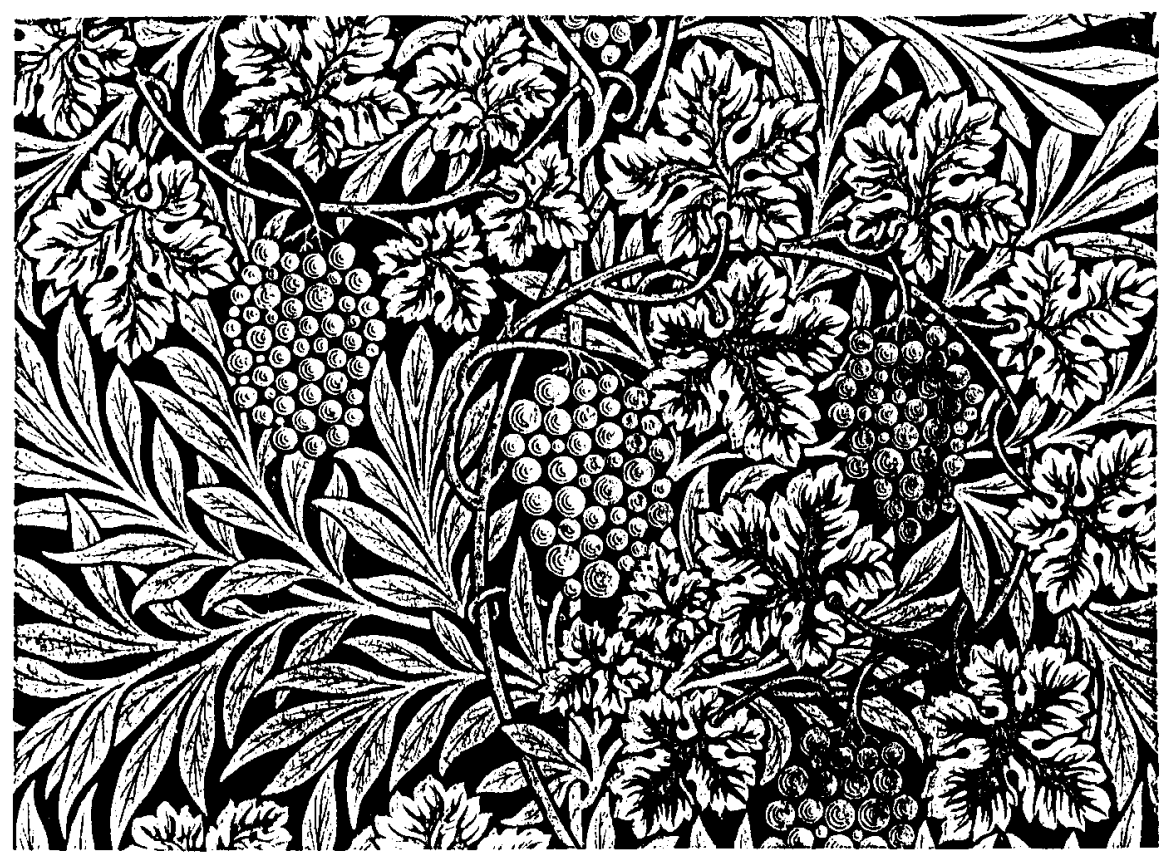

WILLIAM MORRIS, Vine (1874), hand printed wallpaper.

$5 \quad$ lbid. 




WILLIAM MORRIS, Three Female Musicians from The Earthly Paradise. 


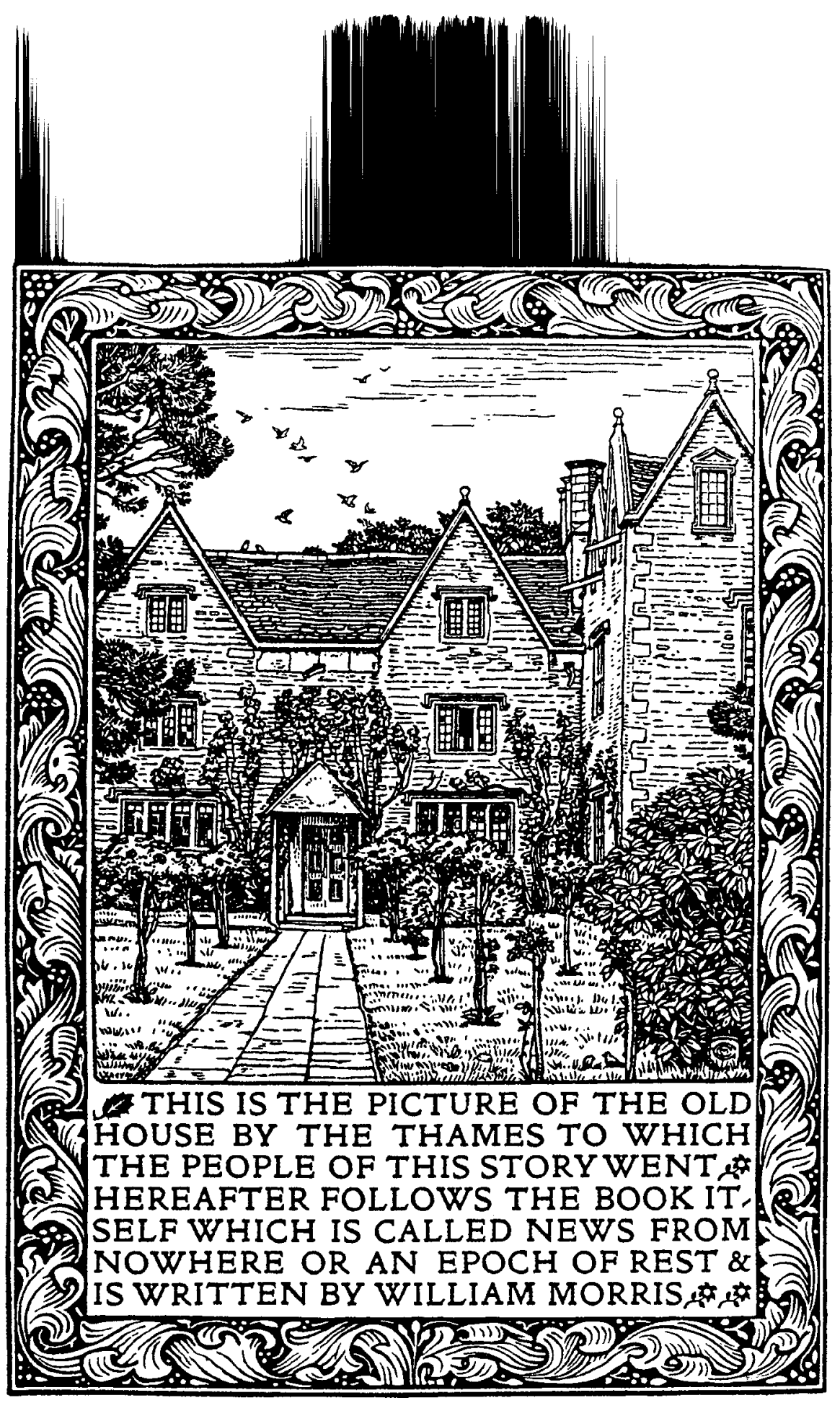

WILLIAM MORRIS, News From Nowhere (Hammersmith: Kelmscott Press 1893) 